\title{
X. A Brief History of the late English Convent at Paris of the Order of the Conception, commonly called the Blue Nuns; in a Letter from John Gage Rokewode, Esq. F.R.S., Director, to Sir Henry Eluis, K.H., F.R.S., Secretary.
}

Read 14th February, 1839.

\section{Dear Sir Henri,}

IN 1798 the Abbé Mann favoured the Society with a short chronological account $^{\mathrm{a}}$ of the religious establishments made by English Catholics on the continent of Europe, noticing among them the Nuns of the Conception at Paris.

The Book of the transactions of this Convent from its foundation to the year 1792, shortly after which it was suppressed, being now in my possession, I beg to transmit to the Society a brief History of the Religious, as the names of some of the noblest English Catholic families will be found among the ladies presiding orer the house, or enrolled in its small community:

a Archæologia, vol. XIII. p. 251.

b MS. on paper, tall folio, without a title, in modern calf. It is divided into these seven parts. 1. Transcripts of the public instruments relating to the foundation of the Convent, beginning with "Permission des Vicaires de Monseigneur le Cardinal de Retz, Archevesque de Paris, pour l'Etablissement de cette maison." II. A diary of the Convent, commencing in these words : "The occasion and manner of the beginning of this Monastery of Bethlem, the first house of our nation of the holy order of the Imnaculate Conception of our Blessed Lady, in the suburbs of St. Anthony at Paris." From the year 1658 to the year 1703 the diary is kept in the same hand-writing; after which the entries are made in different hands, as the circumstances seem to have arisen. The Diary terminates abruptly in 1792. III. Transcripts of the official documents relating to the election of the abbesses and officers of the Convent ; the last document is dated 2Sth August, 1788. IV. The professions of the community; the formula being transcripts down to the year 1679, after which occur, in every instance, the original signatures of the professed. V. An Obituary of the community, intitled "Burials," closing with the entry of the burial at Norwich in 1810, of the last Abbess,

VOL. XXVIIT.

$2 \mathrm{C}$ 
In 1658 the English Convent of nuns of the third order of St. Francis, called the Conception, founded at Nieuport in Flanders, which then contained forty-eight Religious, was, in consequence of heavy losses sustained in the wars that ravaged the country, obliged to reduce its numbers. Some of the community went to England, some were sent to Flanders, and others came to France and were the founders of the convent at Paris.

The Religious destined for France, on their arrival at Ghent, chose Angela Jerningham for their Superioress, who had the following ladies under her care: Margaret Floyd, ${ }^{\mathrm{c}}$ Ann Hawkins, ${ }^{\mathrm{d}}$ Christina Thorold, and Lucy Fortescue, ${ }^{\text {e }}$ professed nuns; Martha Figg, a lay-sister; Dorothy Acton, a novice; and Mary Penny, ${ }^{\mathrm{f}}$ a young gentlewoman, pensioner.

These sailed from Flushing for St. Vallery en Somme, and proceeded, under the protection of Father Peter Cape, guardian of the Franciscans at Douay, to Orleans, intending to have established themselves in that eity; but, the Bishop of the diocess not being willing that they should remain there, they went to Paris. Their resources, on their arrival, were nearly exhausted, as they had brought with them from the Convent at Nieuport only two hundred pounds; however, by the exertions of friends they found themselves established at a baker's house in St. Jacques, which, through the means of Lewis Stuart, 5 commonly called Lord Aubigny, was favoured with privileges placing them in some measure on the footing of persons dwelling in an hospice. They lived for a time entirely upon charity, being supplied with daily provisions by their neighbours. In 1659 Christina Thorold returned to Nieuport, but the community was joined by three other Religious of that Convent, namely Mary Jerningham sister of Angela the superioress, Catharine Knevett, and Elizabeth Timperly. The lady last named, one of the nuns

Elizabeth Green. VI. The Superiors given by the Archbishop of Paris to the Religious. VII. The Confessors of the house.

This book was given in evidence before the House of Lords in 1812, in the Stafford Peerage case.

c Died 29 Sept. 1664. d Died 4 May, $1689 . \quad$ e Returned to England.

f Daughter of George Penny, of Poole, in Dorsetshire, Esquire, by his wife, Jane Perkins, of Ufton Court, in Berkshire, professed 8 Dec. 1661 ; died 9 November, 1664.

g Dodd's Charch History, vol. iii. p. 239, and Dugdale's Baronage-Stuart Duke of Richmond; according to the Diary of the Conception Lewis died in 1666. 
who had gone to England, brought with her from her family, which was seated at Hintlesham in Suffolk, and connected with Cornwallis, Bedingfeld, and Jerningham, five hundred pounds for the assistance of the new establishment. In a short time the Religious were in a situation to purchase land, and supported by Lord Aubigny, they obtained permission ${ }^{\mathrm{b}}$ from his Eminence Cardinal Retz, Archbishop of Paris, to buy a house and garden in the Rue Charenton, Fauxbourg St. Antoine, which they took possession of in the month of April, 1660. The purchase cost them 2,600 pistoles. Angela Jerningham was confirmed Abbess of the new community, but, with permission, she returned with her sister to Nieuport at the beginning of the following year, and Elizabeth Timperly was chosen in her place.

Down to this time the Convent professed the rule of their parent monastery, the third order of St. Francis. They now obtained from Pope Alexander VII. a bulli to take the rule of the Conception of the Blessed Virgin, and on the 8th of December 1661, being the feast of the Order, the Religious made their vows accordingly. From the colour of their habit they were commonly called the Blue Nuns. In 1670, Hardouin, Archbishop of Paris, approved j of the convent, on condition that it remained subject to his jurisdiction, and the King confirmed $\mathrm{k}$ the establishment. The constitutions of the Religious were confixmed by the Archbishop of Paris in 1680, and letters of establishment were obtained from the Parliament of France, in 1704, the Queen ${ }^{1}$ of England, Mary D'Este, using her influence on the occasion.

A small steeple with a bell was erected in 1669 for the Religious by some French ladies, one of whom, Madame Beaudauphin, laid the first stone of the conventual church in 1672. On the feast of the Conception in the the following year, the church was blessed, with the permission of the Archbishop of Paris, by Walter Montague, Abbot of Saint Martin's (son of Henry:

h License of the Vicar General, dated 12 th January 1660, granted on the petition of the seven professed nuus in community, under their religious names of sisters Angela Alexis, Mary Ignatius, Catharine Louisa, Margaret Bruno, Anne Bonnaventura, Elizabeth Anne, and Lucy Mechtildis.

i Bull dated 7 Sept. 7 Pontif.

j Approbation dated 22 March, 1670.

k Confirmation Louis XIV. dated at Douay, 27 May, 1670.

1 In 1673 the Queen, then Duchess of York, in passing through Paris bestowed upon the Convent forty pistoles to pray for her prosperity in England. The year before the abdication Father Shireburne, President of the Benedictines, obtained from the Queen a pension of forty pounds a year for this Convent. 
Earl of Manchester), who was a contributor towards the building, and an active promoter of the interests of the Convent. This church becoming insufficient for the increasing community, a donation of a thousand pounds from the Duchess ofCleveland (whose daughter,m Lady Barbara Fitzroy, was a pensioner in the Convent) tempted them to build another, and to convert the old church into a choir for the new. It was begun in 1677, but a want of funds and increasing troubles in England, involved the Convent in temporary difficulties, and the new church was not finished until 1690, being consecrated by the Bishop of Rodes on the 16th of November in that year. For the completion of the edifice the Convent was much indebted to the disinterested zeal of Monsieur de Jeunay, the architect of the French King, employed in the building; and among the most active friends, under the difficulties of the occasion, was Lady Hamilton, afterward Duchess of Tyrconnel. Sir Francis 'Throckmorton gave an organ; John Layborne, late president of Douay College, a chalice and patten; Madame Villembré, a silver lamp; and the Pope, a privileged altar, for the new church. The Religious were frequently engaged in buildings, and in 1743 were obliged, at a cost of nearly fifty thousand livres, to rebuild their conventual house, the foundations of which had suffered from a then recent inundation.

From the commencement of the establishment the Religious received pensioners in their house, and the Convent became the refuge about the time of the abdication of King James II., and subsequently, of many English ladies. Lord Thomas Haward, a younger son of Henry VIth Duke of Norfolk, obtained permission from the Archbishop of Paris in 1689 for four of his sons, all under six years of age, to dwell in the convent, where his young daughter was also placed. The school opened by the Religious was occasionally frequented by some of the chief Catholics of England.

Notwithstanding the assistance which the Convent received at times from their friends in England, and the annual charities of the royal family and clergy, and of some of the nobles of France, the Religious were often embarrassed in their circumstances. The revenue of the house in 1788, ex-

m Lady Barbara Fitzroy died 4th January 1734, and is buried in the choir of the collegiate church of Manchester. Near this lady reposes William Dawson, Esq., who desired to be buried with her, not only to testify his gratitude to a kind benefactress, "but because his fate was similar to hers ; for she was disowned by her mother, and he was disinherited by his father." 
clusive of scholar's' pensions, was 21,597 livres, 10 sous, equal to $£ 900$. British: At that time the number of Religious was thirteen choir nuns, three laysisters, and three novices; and there were ten scholars, whose pensions came to 5420 livres. The troubles in France, which began in 1789, had deprived them of some of their revenue in 1791, when the last account stated in the Convent book was taken.

The Stafford and Howard families were always powerful supporters of the establishment; and among their French benefactors, we must record the name of Monsieur du Vivier, a doctor of Sorbonne, who, in 1714, bequeathed to the Convent all his property which had not come to him by succession from his family; and whose houses produced the Convent, in 1732 , an income of 4691 livres.

In 1794 the French authorities took possession of the convent, and the religious were removed, first to the house of their confessor, and afterward to the English convent of the Austin nuns ${ }^{n}$ at Paris, where they were received with tenderness by Mrs. Lancaster, the Superioress. They continued there, as prisoners together, from the 14th November, 1794, till the $2 \mathrm{nd}$ of July, 1795, when they were allowed to return to their own convent. Their property was under sequestration, but the Religious were permitted to remain in quiet possession of it until the decree of the Directory in 1799 for the confiscation of English establishments in France, under which all their property, real and personal, was sold, the ladies being driven to seek an asylum in their native country.. In 1800 such of the Religious as were then living in community, except Lady Anastasia Stafford, who remained at Paris, came over to England, and by the kindness of the Jerningham family (whose generosity was extended not only to these Religious, but to many of the French emigrants) were settled at Norwich, where the last Abbess of the Convent died in 1810. The circumstances attending the coming over to

n The community removed to the convent of the Austin nuns consisted of fourteen professed nuns, a lay sister, and a novice; two of the nuns died during their abode there. The novice and three of the nuns, on obtaining their liberty, went to England; and one of these ladies, Mrs. Ann (Teresa) Lonergau, of the city of Waterford, was the last survivor of the community, dying in Ireland in 1838.-Letter dated 1 st February, 1839, to the writer of this memoir, from Madame Finchet, present superioress of the Austin nuns at Paris. 
this country of the Religious are detailed in the Convent obituary under an entry of the burial in 1804 of their ancient Vicaress, and the document deserves a place here.

"On the 2nd December, 1804, our venerable and dear Mother Mary Augustine (alias Mary Lloyd ${ }^{\circ}$ ) departed this life, in the 89th year of her age, and the 62nd of her religious engagement.

"This most valuable member of our expiring community, who so long edified us with her uninterrupted virtuous example, had been educated at Bruges, at the convent of the English Austin nuns, where she had first felt her vocation for a cloistered life. But the Duchess of Norfolk, under whose protection she was, on returning to England, wishing her to settle at Paris in our Convent, she complied with her desire, and most fortunate we were in having among us one so highly gifted in judgment and capacity. She was for many years first mistress of the school, and had the talent of making herself both loved and feared. Her attachment to our reverend mother, Benedict Lee (daughter of the Earl of Lichfield, who died abbess) was most tender and affectionate. She never left her during her long illness, and had at length the sad affliction of beholding her taken off in the prime of life. Mother Austin was afterwards Vicaress several years; and after having gone through all the horrors of the French revolution, when there was a hope that we might have been suffered to remain (though miserably ill off) in our Convent, we had on order to leave it, as being national property and disposed of as such. Thus in the cold month of January 1800, this venerable good religious woman, in the 84th year of her age, undertook, with five of her sister nuns, the coming over to England and arrived safely in London, where Sir William Jerningham was happy to give them an asylum at his house in Bolton Row. After staying some weeks there this small community, then consisting of six, came to Norwich, and were comfortably settled in a convenient house in St. George's, Colegate. Here we began again our regular observances, saying the Divine Office together; and our good Mother Austin was a constant example of every virtue to us. The time, however, came that it pleased Almighty God to reward her long and faithful services, and a most painful malady came upon her, which released

o Daughter of Godfrey Lloyd, of Wales, by his wife Dorothy Wharton, of Sussex. 
her out of this world after many days of great sufferance. She was buried in the churchyard of St. George's Colegate, Norwich."

According to the rule of the Religious of the order of the Conception, the election of an Abbess was to take place every three years, which rule, after the resignation of the second Abbess, Elizabeth Timperley, was generally observed; and the frequency of the succession gives us an opportunity of recording many names of the community in the following list of abbesses of the convent.

I. Angela (Alexis) Jerningham, of the family of Jerningham, ${ }^{p}$ of the county of Norfolk, chosen Superioress in 1658, being in the 56th year of her age and 36th of her profession ; confirmed Abbess 2nd February, 1660, resigned 22nd of January following, and returned to the English Convent at Nieuport, to which she belonged.

II. Elizabeth (Anne) Timperly, sister of Thomas Timperly, of Hintlesham, in Suffolk, Esq. chosen Abbess 25th January, 1661, in the 33rd year of her age and 8th of her profession; resigned 10th August, 1681, and retired to a French monastery. Frances Timperly, her sister, died 19th November, 1661, having made her profession on her deathbed, and is buried in the convent.

III. Susanna (Joseph) Hawkins, daughter of John Hawkins, q of Nash Court in Kent, Esq. by Mary his wife, sister of Martin Woolascot, ${ }^{\mathrm{r}}$ of Woolhampton in Berkshire, Esq.; professed 3rd of May 1662, chosen Abbess 14th August 1681, resigned 26th May following. Her sister Anne was also a professed nun of the convent, and died 4th May 1689.

IV. Catharine (Mechtildis) Rice, daughter of Bartholomew Rice, of Limerick in Ireland, by Eleanora Sexton his wife ; professed 12 th November, 1671; chosen Abbess 26th May, 1682; died 4th February 1729, aged, according to the entry of her profession, 75 , according to the entry of her burial, 80 ; buried in the cloister, on the left hand going into the choir.

V. Mary (Teresa) Harris, daughter of Richard Harris, of Cambridge, by his wife Martha, sister of John Hawkins, of Nash Court in Kent, Esq.; professed 2nd August 1678; chosen Abbess 10th June 1686.

VI. Elizabeth (Victoria) Crane, daughter of William Crane, of the county

p Dodd's Church History.

a Joln Hawkins died 29th July $1673 . \quad$ r Martin Woolascot died 1673. 
of Norfolk, Esq. by his wife Frances Bond, of Cornwall; professed 24th August 1664; chosen Abbess 14th June 1689; died 21st January 1699, aged 52.

VII. Mary (Teresa) Harris, re-elected 14th June 1692.

VIII. IX. Susanna (Joseph) Hawkins, re-elected Abbess 14th June 1695, and continued Abbess by re-election 17th June 1698; died 13th June 1704, aged 80 .

X. Margaret (Constantia Henrietta) Mannock, daughter of Sir Francis Mannock, of Giffard's Hall in Suffolk, Baronet, by his wife Mary, daughter of Sir George Heneage, of Hainton in Lincolnshire; professed 5th of August 1671 ; chosen Abbess 17th October 1701.

XI. XII, Mary (Teresa) Harris, re-elected Abbess 17th October 1704, and continued Abbess by re-election 20th October 1707; died 19th August 1719, aged 73 ; buried in the cloister by the choir door.

XIII. XIV. Margaret (Constantia Henrietta) Mannock, re-elected Abbess 24th April 1711, and continued Abbess by re-election 24th April 1714.

XV. Anne (Gertrude Frances) Hancock, daughter of Robert Hancock, of

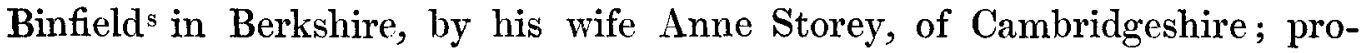
fessed 1st May 1701; chosen Abbess 24th April 1717; returned to England in the following year on account of her health.

XVI. Margaret (Constantia Henrietta) Mannock, re-elected Abbess 8th June 1720; died 25th April 1725, aged 78, buried in the cloister.

XVII. Jane (Henrietta Clementina) Darell, daughter of Marmaduke Darell, of Fulmer in Buckinghamshire, Esq. by his wife Catharine Palmer, sister $^{\text {t }}$ of Roger Earl of Castlemaine; professed 25th January 1667 ; chosen Abbess 8th June 1723; died 29th April 1739, aged 80 ; buried in the cloister near the chapter-house door ; her sister Barbara Darell made her profession at the same time with her, and died in the Convent 28th August 1679.

XVIII. XIX. Mary Genevieve Ogilvy, daughter of Thomas Ogilvy, of Merns in Banffshire, Esq. by Elizabeth his wife; professed in the presence of Mary "Queen of James II. 30th January 1693 ; chosen Abbess 26th June 1726 ; continued Abbess by re-election 21 st July 1729.

Antiquities of Berkshire, vol. ii. p. 447.

t MS. Collection of Pedigrees, by Manson, penes C. G. Young, Esq.

u It is stated in the Diary that the Queen helped to put the black veil on the professed lady. Her 
XX. XXI. Louisa (Mary) Stafford, daughter of the Honourable John Stafford by his wife Mary, daughter of Sir John Southcott, of Mestham in Surrey; which John Stafford, younger son of William Viscount Stafford, was father of William and John Paul, severally Earls of Stafford; professed ${ }^{x}$. 28th November 1720; chosen Abbess 20th September 1732, and continued Abbess by re-election 1st October 1735 .

XXII. Mary (Genevieve) Ogilvy, re-elected Abbess 1st October 1738; died 28th February following, aged 68 ; buried in the cloister.

XXIII. IV. V. VI. Louisa (Mary) Stafford, re-elected Abbess 7 th March 1739 ; continued Abbess by re-election 7 th March 1742; by license from the Archbishop of Paris, re-elected Abbess 17th March 1745; and continued Abbess by re-election 24th April 1748; died 30th September 1764, aged 66; buried at the request of her niece, Madame de Rohany Chabot, in the garden of the cloister. Xaveria Beatrix, sister of Louisa Stafford, made her profession at the same time with her, and dying 20th December 1770, lies buried in the cloister near the entrance of the house.

XXVII. Anne (Mary-Agnes) Howard, daughter of Bernard Howard, of Twyford, in the county of Hants, esq. by his wife Anne, daughter of Christopher Lord Teynham, which Bernard Howard, grandson of Philip Earl of Arundel, was grandfather of Bernard Edward, present Duke of Norfolk; professed 4th September, 1736; chosen Abbess, 24th April, 1751; and continued Abbess, by re-election, 24th April, 1754.

XXVIII. IX. The Right Honourable Lady Frances (Benedicta) Lee, daughter of George Henry second Earl of Lichfield, by Frances, daughter of Sir John Hales, of Woodchurch, in Kent, Baronet; professed 12th November, 1744 ; chosen Abbess, 6th April, 1757 ; and continued Abbess, by re-election, 26th April, 1760; died 29th January following; buried in the cloister.

Majesty's signature, and that of Dr. Betham, preceptor of the Prince of Wales, appear at the foot of the formula of the profession.

$x$ Vide the printed evidence in the Stafford Peerage case, page 145, for the formula of the professions of Mary Louisa Stafford, and Xaveria Beatrix her sister.

y Lady Mary Stafford, wife of Guy Augustus, Count de Rohan Chabot, brother to the Duke de Rohan : this lady was a great benefactress to the Convent.

VOL. XXVIII. 
XXX. Anne (Mary-Agnes) Howard, re-elected Abbess, 18th May, 1761; and continued Abbess, by re-election, 21st May, 1764. In the Convent Obituary occurs the following entry relating to this Lady :-

"November 1, 1794. On this day our venerable and dear mother, MaryAgnes, (alias Anne-Mary Howard,) departed this life of trial, aged 74, having made her religious vows 58 years. At the early age of 15, this wise virgin felt the nothingness of worldly advantages, and desired rather to take shelter under the cross of Christ.

"She was highly gifted with all that leads to distinction. A fine understanding, most pleasing elocution, and amiable manners. And it had been remarked, by people who were conversant with the high circles in society, that the polish of her eonversation was such, as could only be produced by the innate virtues of her comprehensive mind. She was twice elected Abbess, and filled that office twelve years; her constitution had always been delicate, and for a long time before her dissolution she was almost continually in the infirmary; but this year was removed from her usual sick-chamber, by the increasing inhuman irregularity of the French Revolutionists, who took possession of our conventual dwelling, and forced our whole community into a small house belonging to our confessor, $\mathrm{Mr}$. Shelley (he being removed prisoner to the Luxembourg); and thus, in a small closet of this apartment, without being able to procure the assistance of any priest, to say prayers, or speak a word of comfort, our dear mother Agnes Howard breathed her last, in sentiments of resigned piety and patient sufferance, that even seemed to affect those sentinels who had accepted the post, of overlooking and preventing our having a help seldom refused to any person in the article of death. She was sensible to the last, and we trust that this increased sacrifice will have added to her immortal crown. She was buried at the Abbaye de St. Antoine."

Among the religious who received the habit from this Abbess was the Right Honourable Lady Lucy Talbot, daughter of George fourteenth Earl of Shrewsbury, who died 3d May, 1787, and lies buried in the avant chœur of the Convent.

XXXI. II. Elizabeth-Mary (Bernard) Green, daughter of Jonas Green, of Barton, in Oxfordshire, by his wife, Mary King, of Herefordshire ; professed 
29th January, 1757; chosen Abbess, 21st May, 1767; and continued Abbess, by re-election, 30th May, 1770 .

XXXIII. IV. The Right Honourable Lady Anastasia (Mary-Ursula). Stafford, daughter of William second Earl of Stafford, by his wife Anne, daughter of George Holman, of Warkworth Castle, in the county of Northampton, Esq.; ${ }^{2}$ professed 19th March, 1740; chosen Abbess, 3d June, 1773 ; and continued Abbess, by re-election, 3d June, 1776.

This lady is recorded in the Convent Obituary in these words :-

"On the 27th April, 1807, died, at Paris, our venerable dear mother Mary Ursula (alias Anastasia Stafford), in the 85th year of her age, and the 67th of her religious profession. Mother Ursula was deprived of her mother (the Countess of Stafford) at a very early age of infaney. She went with her two sisters, attended by her nurse, to the school at Hammersmith, and at six years of age, her elder sister being eight, and the other three years, they went over to the convent of Poor Clares at Rouen, to be brought up in their school. In this retirement she soon understood the folly of all worldly enjoyment, and resolved to make the Cross of Christ the only object of her mind. Her years were, however, yet too few, for to be permitted to make any permanent choice. In July, 1735, being in her thirteenth year, she was placed, with her younger sister, in our school, the Earl of Stafford being desirous his daughters should be under the tuition of their aunt, who was his sister, and had lately resolved to receive young pensioners. This change of place did not make any in her good resolution hut she agreed to remain at Paris, as such appeared to be the wish of her friends. Thus, at 18 years of age, she gave up all the advantages of birth and fortune, to make herself the humble spouse of Christ.

"She was endowed with a very uncommon understanding and quickness of parts, and would have been distinguished in any sphere of life; but she bowed with cheerfulness and resignation to the choice of her first years.

"She was six years abbess, and some years after, having fallen into an uncertain state of health, she for some time retired to a French convent of Urselines at Argenteuiel. The French revolution restored her to us, as the

z Vide the printed evidence in the Stafford Peerage case, p. 148. 
other convent was broken up; but before we left Paris, Mother Ursula Stafford had desired a society of religious women, called Les Filles Orphelines, to give her an apartment at their house, where she had every care and attention paid to her, not only by them, but by the watchful charity of Mrs. Canning at the English convent of Austin Nuns, who was in the immediate neighbourhood. In January, 1800, when we took our leave of her, she expressed the most generous anxiety for our welfare, and only claimed the benefit of our prayers: a tribute she had every title to receive. Her health growing weaker, and the vivacity of her spirits absorbed by years, she with calmness and confidence gave up a life that had been consecrated to her Creator, from the earliest days of her youth."

Lady Anne Stafford, sister of the Abbess last named, made her profession ${ }^{2}$ in this Convent 18th of April, 1743, and died 6th of May, 1792, being buried in the garden of the cloister on the left side of the cross.

XXXV. VI. VII. Elizabeth Mary (Bernard) Green, re-elected Abbess 14th of June, 1779, and continued Abbess, by re-election, 19th of June, 1782, and by license from the Archbishop of Paris re-elected Abbess 18th June, 1785.

XXXVIII. IX. Elizabeth (Winifrid Joseph) Stock, daughter of Thomas Stock, of Newland, in the county of Gloucester, by his wife Mary Edmonds, of the county of Monmounth ; professed 19th April, 1746; chosen Abbess, 18th of August, 1788; died 30th of January, 1799 ; buried in the parish church of St. Marguerite.

XL. Elizabeth Mary (Bernard) Green, the last Abbess of the community, re-elected Abbess, it is presumed on the 7th of November, 1791.b

"On the 8th of April 1810 (being Passion Sunday)" adds the obituary to which we have had recourse, we hope not too often, "our reverend and dear mother Abbess, Mary Bernard, alias Elizabeth Green, after being in a state of general debility for three years, brought on by a paralytic affection,

a Vide Stafford Peerage case, p. 147.

b It appears from an incidental entry in the Convent book, that an election took place, 7 th November, 1791, and a doubt arises from the obit of Mrs. Stock, whether she was not then re-elected for three years. It is, however, presumed that Mrs. Green was re-elected on the occasion, as that lady, according to Madame Finchet, held the dignity some time before she went with the community to the Austin Nuns; at all events, Mrs. Green succeeded Mrs. Stock, and was the last abbess of the Convent. 
departed this life in the 76th year of her age, and the 54th of her religious profession.

"This good Abbess (the last of our community re-elected previous to the fatal revolution of all order) was born, endowed with superior abilities, enclosed in the mildest temperature of disposition. In the most difficult time for all government, she was satisfied with gently pursuing the point of right, and thus, by persevering prudence, after weathering through part of the sad storm of the French Revolution, she brought the remainder of her reduced community safely to England, and to the asylum prepared for them at Norwich.

"She was brought up in our school from fourteen years of age, and from that early period may be said to have passed through life without a fault. She was particularly noticed by our reverend mother Benedict Lee, who; so enlightened herself, knew how to distinguish the seed of virtue and ability in others. She was often employed by her as secretary both in French and English, her writing being equal to copper-plate, and her mind adopting with quickness every idea that was to be conveyed.

"She was successively mistress of the school, procuratrice, and Abbess; and always accompanied by the same cheerful humility, made herself beloved by all. Her decease was the sad moment of dispersion for the very few Religious who then inhabited Norwich.

"This venerable Abbess was buried like her sisterhood in the churchyard of St. George's, Colegate, Norwich, April, 1810."

Among the Religious buried in the Convent, whose names do not before occur in this memoir, we may mention the following:-Dorothy, daughter of John Southwell, of the county of Norfolk, by his wife Catharine St. George ; Anne, ${ }^{d}$ daughter of Valentine Sanders, of the county of Surrey, Esq. by his wife Anne, daughter of Sir Francis Mannock, Baronet; Martha, daughter of John Chancellor, Esq. N. B. by his wife Jane, daughter of Sir Robert Forbes ; Elizabeth Anne, ${ }^{f}$ daughter of Thomas Whettenhall, of Peckham Place, in Kent, Esq. by his wife Anne, daughter of Henry Saunders, of Shankton,

c Died 21 st June, 1734.

e Died 8th February, 1762: d Died 3rd June, 1717.

$f$ Died 14th December 1723. 
in Leicestershire, Esq. ; Anne Ursula,g daughter of John Jenison, of Great Walworth Hall, in the Bishopric of Durham, by his wife Sarah Williams, of the county of Hereford; Teresa, ${ }^{\text {b }}$ daughter of Charles Butler, of Lancashire, Esq. by his wife Elizabeth Newton, of Northumberland; Winifrid, ${ }^{i}$ daughter of Thomas Stapleton, Esq. of the county of Tipperary, in Ireland; Mary, daughter of Thomas Sackville, Esq. of the county of Northumberland, by his wife Elizabeth Darell, of Kent ; Anne, ${ }^{1}$ daughter of Thomas Eyre, of Thorpe, in Derbyshire; Margaret, ${ }^{\mathrm{m}}$ daughter of Jordan Langdale, Esq. of Cliffe, in the county of York, by Mary his wife, sister of Charles Lord Stourton ; Ursula, ${ }^{n}$ daughter of Vincent Eyre, of the county of Derby, Esq. by Anne Bostock, his wife. Here also were interred Emanuel Christmas, ${ }^{\circ}$ John Massey, ${ }^{p}$ William Daniel, $\mathrm{q}$ and Charles Corn, ${ }^{\mathrm{r}}$ in priest's orders, confessors of the Religious, all of whom were benefactors to the house.

In the choir of the convent church was deposited the heart of Williams. second Earl of Stafford; likewise the heart of Monsieur Formentin, ${ }^{\mathrm{t}}$ surgeon of the convent, who, during fourteen years, exercised the most unbounded charity towards the Religious. Here also, lastly, among persons not being Religious professed, were buried Henrietta " daughter of Sir Patrick Trant; ${ }^{x}$ Mrs. Catherine Whettenhall; ${ }^{y}$ Scholastica Tempest; ${ }^{2}$ Miss Phipps ; Mary Rothe, ${ }^{\mathrm{a}}$ daughter of Mr. Rothe an East India Director; Mary Howard, ${ }^{\mathrm{b}}$ daughter of Charles Howard of Greystok, sister of Charles late Duke of Norfolk; and Mrs. Dillon, ${ }^{c}$ widow of General Dillon, father of the Bishop of Evreux.

I am, dear-Six Henry, yours faithfully, John Gage Rokewode.

g Died 21 st April, 1770.

k Died 29th May, 1793.

n Died 8th July, 1763.

q A priest from Douay College, died 9th February, 1761 .

s In June, 1734.

$\times$ Died 10th January, 1717.

y A Benedictine nun of the Chant de LAllouette, buried 24th February, 1735.

$z$ Died 2nd September, 1741.

b Died 15 th November, 1756.
Died 27 th May, 1677.

h Died 6th January, 1738.

1 Died 1st May, 1762.

- Died 30th March, 1748.

a Died 17th October, 1756.

c Died 5th August, 1757. i Died 17th March, 1729.

$m$ Died 17th November, 1755. p Died 11 th August, 1716.

r Died 9th November, 1777.

u June, 1708. 